\title{
Photocatalytic Hydrogen Evolution via Water Splitting: A Short Review
}

\author{
Yifan Zhang ${ }^{1}$, Young-Jung Heo ${ }^{1}$, Ji-Won Lee ${ }^{1}$, Jong-Hoon Lee ${ }^{1}$, Johny Bajgai ${ }^{2}{ }^{\circledR}$, Kyu-Jae Lee ${ }^{2, *}$ \\ and Soo-Jin Park ${ }^{1, *}$ \\ 1 Department of Chemistry and Chemical Engineering, Inha University, 100 Inharo, Incheon 22212, Korea; \\ zyf9106@gmail.com (Y.Z.); heoyj1211@gmail.com (Y.-J.H.); lj529@naver.com (J.-W.L.); \\ boy834@naver.com (J.-H.L.) \\ 2 Department of Environmental Medical Biology, Wonju College of Medicine, Yonsei University, Wonju 26426, \\ Korea; johnybajgai@gmail.com \\ * Correspondence: medbio9@gmail.com (K.-J.L.); sjpark@inha.ac.kr (S.-J.P.); Tel.: +82-32-860-7234 (S.-J.P.); \\ Fax: +82-32-860-5604 (S.-J.P.)
}

Received: 23 October 2018; Accepted: 8 December 2018; Published: 12 December 2018

\begin{abstract}
Photocatalytic $\mathrm{H}_{2}$ generation via water splitting is increasingly gaining attention as a viable alternative for improving the performance of $\mathrm{H}_{2}$ production for solar energy conversion. Many methods were developed to enhance photocatalyst efficiency, primarily by modifying its morphology, crystallization, and electrical properties. Here, we summarize recent achievements in the synthesis and application of various photocatalysts. The rational design of novel photocatalysts was achieved using various strategies, and the applications of novel materials for $\mathrm{H}_{2}$ production are displayed herein. Meanwhile, the challenges and prospects for the future development of $\mathrm{H}_{2}$-producing photocatalysts are also summarized.
\end{abstract}

Keywords: photocatalysis; $\mathrm{H}_{2}$ generation; water splitting; solar energy

\section{Introduction}

The development of renewable green energy sources is a critical challenge for modern society. $\mathrm{H}_{2}$ is environmentally friendly, renewable, and considered to be an ideal candidate for an economically and socially sustainable fuel [1-6], and was previously regarded as an alternative energy source. Interestingly, some researchers also found that $\mathrm{H}_{2}$-rich water has neuron effects owing to its antioxidant properties. Although the deep mechanism is not clear, more and more researchers made an effort to study the biological function of $\mathrm{H}_{2}$ [7-21]. To date, almost all $\mathrm{H}_{2}$ gas production processes in the industry are based on natural gas, coal, petroleum, or water electrolysis. These traditional preparation methods are limited due to the associated $\mathrm{CO}_{2}$ emissions and high energy consumption. Hence, it is urgent to develop a low-cost method for efficient $\mathrm{H}_{2}$ generation and, thus, support the emerging $\mathrm{H}_{2}$ economy.

The sun provides an energy output of $\sim 3 \times 10^{24} \mathrm{~J}$ per year, which is approximately 12,000 times higher than the current energy demand. Therefore, solar energy can act as a sustainable alternative energy source in the future. To date, the transformation of solar energy into $\mathrm{H}_{2}$ via water splitting is deemed as a desirable $\mathrm{H}_{2}$ preparation method to solve the energy crisis [22,23].

The proper use of $\mathrm{H}_{2}$ requires insight into the physical properties of $\mathrm{H}_{2}$ molecules. As we know, the lengths and strengths of hydrogen bonds are exquisitely sensitive to temperature and pressure. Meanwhile, the charges of $\mathrm{H}_{2}$ molecules also vary with temperature [24] because the spin direction of the nucleus in the $\mathrm{H}_{2}$ molecule changes depending on the temperature, and an energy difference occurs between $\mathrm{H}_{2}$ molecules. The para- $\mathrm{H}_{2}$ fraction changes with temperature, and it is 
necessary to understand the characteristics of $\mathrm{H}_{2}$ molecules according to temperature [25]. During the reaction, hydrogen can be used safely at room temperature; however, it is rather dangerous in high-temperature environments.

As we know, $\mathrm{H}_{2}$ gas, often called dihydrogen or molecular $\mathrm{H}_{2}$, is a highly flammable gas with a wide range of concentrations between $4 \%$ and $75 \%$ by volume. Meanwhile, $\mathrm{H}_{2}$ is the world's lightest gas. The density of $\mathrm{H}_{2}$ is only $1 / 14$ of that of air. At $0{ }^{\circ} \mathrm{C}$, the density of $\mathrm{H}_{2}$ is only $0.0899 \mathrm{~g} / \mathrm{L}$ at standard atmospheric pressure, which is the smallest-molecular-weight substance; it is mainly used as a reducing agent. The enthalpy of combustion is about $-286 \mathrm{~kJ} / \mathrm{mol}$, which can be displayed by the following equation: $2 \mathrm{H}_{2}(\mathrm{~g})+\mathrm{O}_{2}(\mathrm{~g}) \rightarrow 2 \mathrm{H}_{2} \mathrm{O}(\mathrm{l})+572 \mathrm{~kJ}(286 \mathrm{~kJ} / \mathrm{mol})$. Currently, $\mathrm{H}_{2}$ is the main industrial raw material and the most important industrial gas. It has various applications in the petrochemical, electronic, and metallurgical industry, as well as in food processing, float glass, fine organic synthesis, aerospace, and other fields. At the same time, $\mathrm{H}_{2}$ is also an ideal secondary energy source. Owing to the properties of $\mathrm{H}_{2}$, the aerospace industry uses liquid $\mathrm{H}_{2}$ as fuel. Now, it is common to produce $\mathrm{H}_{2}$ from water gas rather than using high-energy-consuming water. The produced $\mathrm{H}_{2}$ is used in large quantities in the cracking reaction of the petrochemical industry and the production of ammonia. Unfortunately, all $\mathrm{H}_{2}$ production methods are highly energy (thermal and electrical) demanding, which limits their application. Thus, it is crucial to find a new method of $\mathrm{H}_{2}$ production.

Fujishima and Honda first reported photocatalytic water splitting using a $\mathrm{TiO}_{2}$ electrode in 1972 [26]. Research on solar $\mathrm{H}_{2}$ production attracted researchers in various fields, such as (1) chemists for the design and synthesis of various catalysts to investigate structure-property relationships; (2) physicists to fabricate semiconductor photocatalysts with novel electronic structures, as predicted by theoretical calculation; and (3) material scientists to construct unique photocatalytic materials with novel structures and morphologies [27-30]. When photocatalysts are illuminated at wavelengths which are suitable to their band gap energy, after the excitation, the charge carriers will either combine or transfer to the surface of the photocatalysts to participate in photocatalytic reactions. For the generation of efficient semiconductor photocatalysts, long-lived charge carriers and high stability are required [31-33].

Significant developments were made toward $\mathrm{H}_{2}$ generation via water splitting over the last several decades by a number of talented researchers [34-38].

Herein, we attempt to sum up the advances achieved to date. Therefore, we briefly summarize the background related to various photocatalysts for $\mathrm{H}_{2}$ generation and the achievements of high-efficiency photocatalysts. The main synthesis routes and modifications for adjusting the band structure to harvest light and enhance charge separation are also discussed.

\section{Principle of $\mathrm{H}_{2}$ Generation via Water Splitting}

In the pioneering study by Fujishima and Honda [27], electrochemical cells were made up for the splitting of the water into $\mathrm{H}_{2}$ and $\mathrm{O}_{2}$, as shown in Figure 1. While the $\mathrm{TiO}_{2}$ electrode was under ultraviolet (UV) light irradiation, water oxidation (oxygen evolution) occurred on its surface, while the reduction reaction ( $\mathrm{H}_{2}$ evolution) occurred on the surface platinum black electrode. With this study in mind, semiconductor photocatalysts were later developed by Bard et al. in their design of a novel photocatalytic system. 


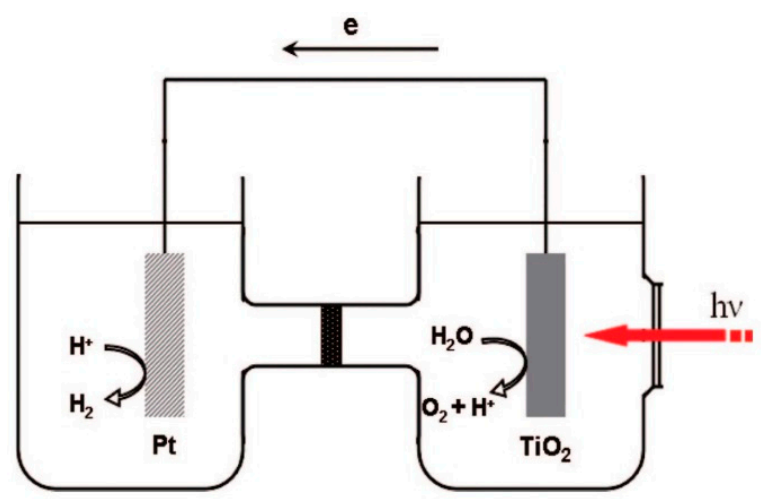

Figure 1. Schematic of a photoelectrochemical cell (PEC). Reproduced with permission from Reference [26]; copyright (1972), Nature Publishing Group.

Figure 2a shows a display of hydrogen evolution by photocatalysts. The photocatalytic reaction occurring on the semiconductor photocatalysts can be divided into three parts: (1) obtaining photons with energy exceeding that of the photocatalyst's band gap, generating electron and hole pairs; (2) separating carriers by migration in the semiconductor photocatalyst; and (3) reaction between these carriers and $\mathrm{H}_{2} \mathrm{O}$ [39-46]. In addition, electron-hole pairs will combine with each other simultaneously. As shown in Figure 2b, while photocatalysts are involved in hydrogen evolution, the lowest position of the conduction band (CB) should be lower than the reduction position of $\mathrm{H}_{2} \mathrm{O} / \mathrm{H}_{2}$, while the position of the valence band (VB) should be higher than the potential of $\mathrm{H}_{2} \mathrm{O} / \mathrm{O}_{2}$ [47-50].

a

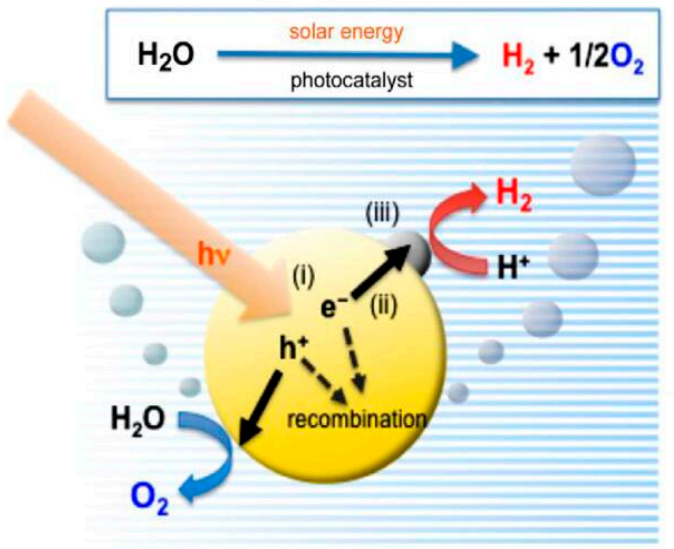

b

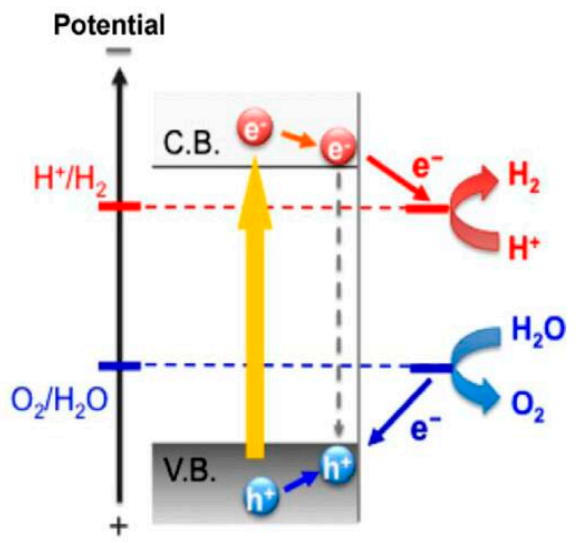

Figure 2. Schematic illustration of hydrogen evolution over photocatalysts. Reproduced with permission from Reference [39]; copyright (2014), Elsevier.

Various photocatalysts were reported to decompose water into $\mathrm{H}_{2}$ and $\mathrm{O}_{2}$ (Equation (1)). As we know, the hydrogen evolution reaction can be separated into two parts: oxidation for the evolution of $\mathrm{O}_{2}$ (Equation (2)) and water reduction to produce $\mathrm{H}_{2}$ (Equation (3)) [51-56]:

$$
\begin{array}{ll}
\mathrm{H}_{2} \mathrm{O} \rightarrow 2 \mathrm{H}_{2}+\mathrm{O}_{2} & \Delta E^{0}=1.23 \mathrm{~V} \\
\mathrm{H}_{2} \mathrm{O} \rightarrow 4 \mathrm{H}^{+}+4 e^{-}+\mathrm{O}_{2} & E^{0}=+1.23 \mathrm{~V} \text { vs. NHE, } p H=0 \\
4 \mathrm{H}^{+}+4 e^{-} \rightarrow 2 \mathrm{H}_{2} & \Delta E^{0}=0 \mathrm{~V} \text { vs. NHE, } p H=0
\end{array}
$$

\section{Photocatalysts for Water Splitting}

Many photocatalysts were created as photocatalysts for hydrogen evolution. Based on these species, they can be divided into three major parts: (1) graphene-based photocatalyst; (2) 
graphitic carbon nitride (g-C3N4)-based photocatalysts; and (3) heterojunction photocatalysts (semiconductor-semiconductor or semiconductor-(metal, element)).

\subsection{Graphene-Based Photocatalysts}

Recently, graphene-based photocatalysts attracted significant attention for enhancing photocatalytic $\mathrm{H}_{2}$ production performance. Graphene is used to enhance photocatalytic efficiency owing to its novel structure and electrochemical properties (Figure 3).

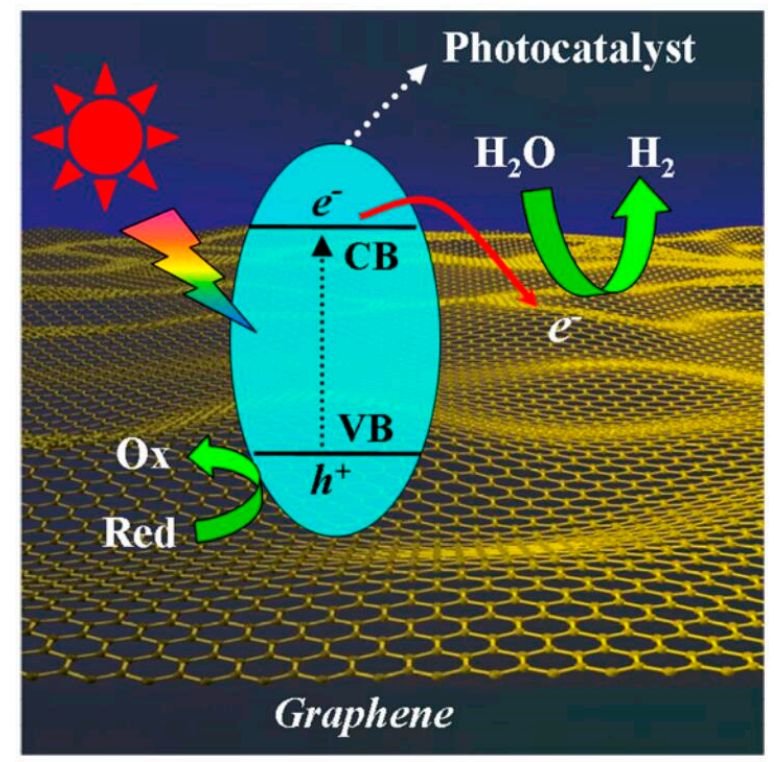

Figure 3. Proposed mechanism of graphene-based photocatalysts. Reproduced with permission from Reference [56]; copyright (2013), American Chemical Society.

To date, many reports regarding the synthesis of graphene-based photocatalysts with improved photocatalytic efficiency were published. Graphene is a well-known two-dimensional (2D) material, which can improve surface area, and its 2D membrane-like structure imparts unique electrochemical properties [57-60]. Generally speaking, photocatalysts prepared by simple physical mixing with graphene will involve only a bit of direct contact with the graphene sheets. This small amount of contact between the photocatalyst and graphene results in weak interactions and inhibits charge transfer rates. Hence, the synthesis of photocatalysts with more interactions is highly needed.

Previously, Kim et al. synthesized novel graphene oxide (GO)- $\mathrm{TiO}_{2}$ photocatalysts [58] in 2013, comprising a core-shell nanostructure with enhanced photocatalytic efficiency (Figure 4). The improved $\mathrm{H}_{2}$ production activity compared to that of $\mathrm{TiO}_{2}$ revealed that the utilization of the core-shell structure enhanced photocatalytic efficiency. This novel structural design offers three-dimensional (3D) close contact between the materials and provides more active sites, which will enhance the charge separation rate and $\mathrm{H}_{2}$ production efficiency [61-63]. 


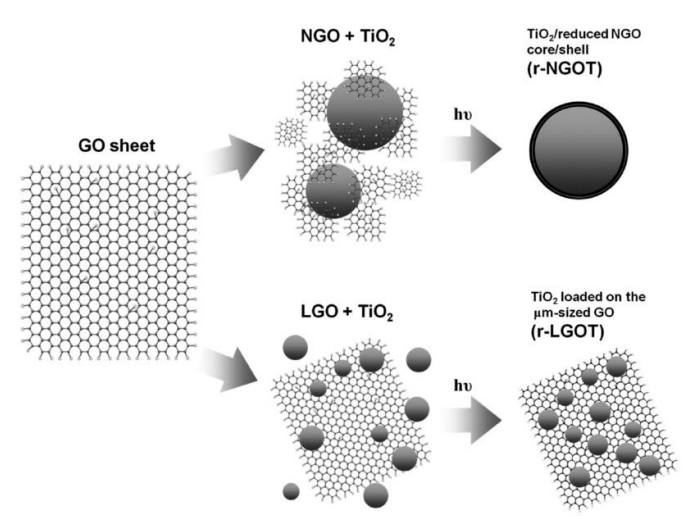

Figure 4. Schematic display of synthetic process of graphene oxide (GO)/ $\mathrm{TiO}_{2}$ and $\mathrm{TiO}_{2} / \mathrm{GO}$. Reproduced with permission from Reference [57]; copyright (2012), American Chemical Society.

Currently, many researchers are more interested in visible-light-driven photocatalysts, which are achieved using band-gap modification or taking graphene as a photosensitizer to broaden the visible-light adsorption range [64-66]. Significant efforts were conducted for building visible-light response systems because of the UV-only response of $\mathrm{TiO}_{2}$, and its nontoxic properties [67]. Recently, it was found that graphene regulating $\mathrm{TiO}_{2}$ involves visible-light adsorption activity. The carbon-layered structure of graphene with enriched $\pi$ electrons forms bonds with titanium atoms. As a result, this strong interaction will shift the band position and reduce the band gap [68-70]. Lee et al. [71] also achieved a lower band gap using a graphene $/ \mathrm{TiO}_{2}$ photocatalyst. The improved photocatalytic efficiency of the graphene $/ \mathrm{TiO}_{2}$ composite owes to the band-gap regulation, which consequently promotes charge transfer rates through the graphene sheets.

\section{2. g- $\mathrm{C}_{3} \mathrm{~N}_{4}$-Based Photocatalysts}

Currently, carbon-nitride-based photocatalysts receive significant attention for their photocatalytic $\mathrm{H}_{2}$ generation owing to a unique electronic structure (Figure 5) [72-77]. This section summarizes recent significant achievements in building $\mathrm{C}_{3} \mathrm{~N}_{4}$-based photocatalysts for $\mathrm{H}_{2}$ evolution. Methods including nanostructure regulation, band-gap modification, dye sensitization, and heterojunction fabrication are highlighted herein.

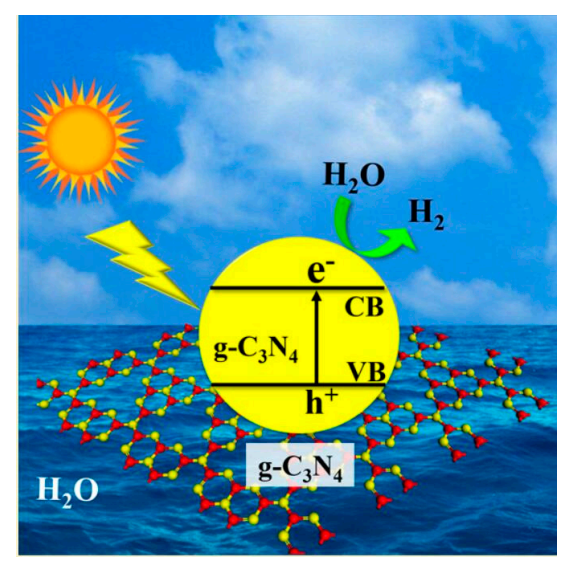

Figure 5. Proposed mechanism of graphitic carbon nitride $\left(\mathrm{g}-\mathrm{C}_{3} \mathrm{~N}_{4}\right)$-based photocatalysts. Reproduced with permission from Reference [72]; copyright (2014), American Chemical Society.

Recently, carbon nitride attracted significant attention following the pioneering research of Wang et al. in 2009 for photocatalytic hydrogen evolution [78,79]. The assumed structure of $C_{3} N_{4}$ is a 2D framework with the tri-s-triazine linked by tertiary amines (Figure 6); it is thermally stable and chemically stable. Pioneering studies regarded g- $\mathrm{C}_{3} \mathrm{~N}_{4}$ as a visible-light-driven phorocatalyst with a 
band gap of approximately $2.7 \mathrm{eV}$ and an appropriate band position for water splitting [80-85]. Hence, $\mathrm{g}-\mathrm{C}_{3} \mathrm{~N}_{4}$ is an ideal candidate for photocatalytic $\mathrm{H}_{2}$ evolution.

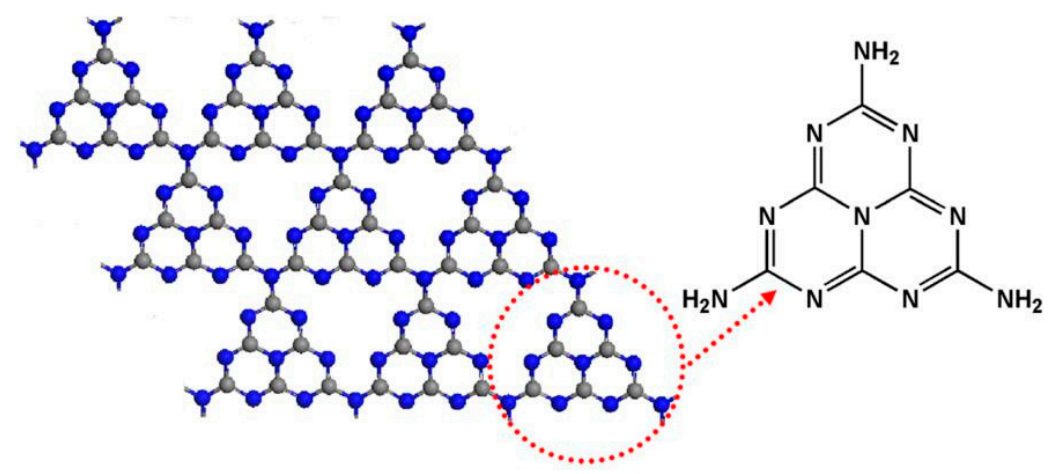

Figure 6. Schematic display of the structure of $\mathrm{g}-\mathrm{C}_{3} \mathrm{~N}_{4}$. Reproduced with permission from Reference [72]; copyright (2014), American Chemical Society.

$\mathrm{H}_{2}$ generation performance using g- $\mathrm{C}_{3} \mathrm{~N}_{4}$ can be promoted with noble-metal particles such as $\mathrm{Au}$ or $\mathrm{Pd}$, which obtain electrons in the $\mathrm{CB}$ to inhibit the charge recombination rate [86-90]. Many researchers are developing metal-free photocatalysts for $\mathrm{H}_{2}$ evolution, and recent reports involved the introduction of non-noble-metal catalysts into g- $\mathrm{C}_{3} \mathrm{~N}_{4}$ photocatalysts, displaying enhanced photocatalytic performance compared to noble-metal catalysts [91-95]. Hou et al. [86] synthesized $\mathrm{MoS}_{2} / \mathrm{g}-\mathrm{C}_{3} \mathrm{~N}_{4}$ composite photocatalysts (Figure 7) in 2018. $\mathrm{MoS}_{2} / \mathrm{g}-\mathrm{C}_{3} \mathrm{~N}_{4}$ increased the surface area and decreased the barrier when the electrons transported, thereby improving the charge transfer rate. The formation of band alignment enabled electron transfer from the $\mathrm{CB}\left(\mathrm{g}-\mathrm{C}_{3} \mathrm{~N}_{4}\right)$ to $\mathrm{MoS}_{2}$. Therefore, the $\mathrm{MoS}_{2} / \mathrm{gC}_{3} \mathrm{~N}_{4}$ nanojunction significantly enhanced $\mathrm{H}_{2}$ evolution efficiency, achieving the highest $\mathrm{H}_{2}$ evolution rate and an optimum quantum efficiency of up to $2.1 \%$ (420 nm), which was higher than $\mathrm{g}-\mathrm{C}_{3} \mathrm{~N}_{4} / \mathrm{Pt}$.

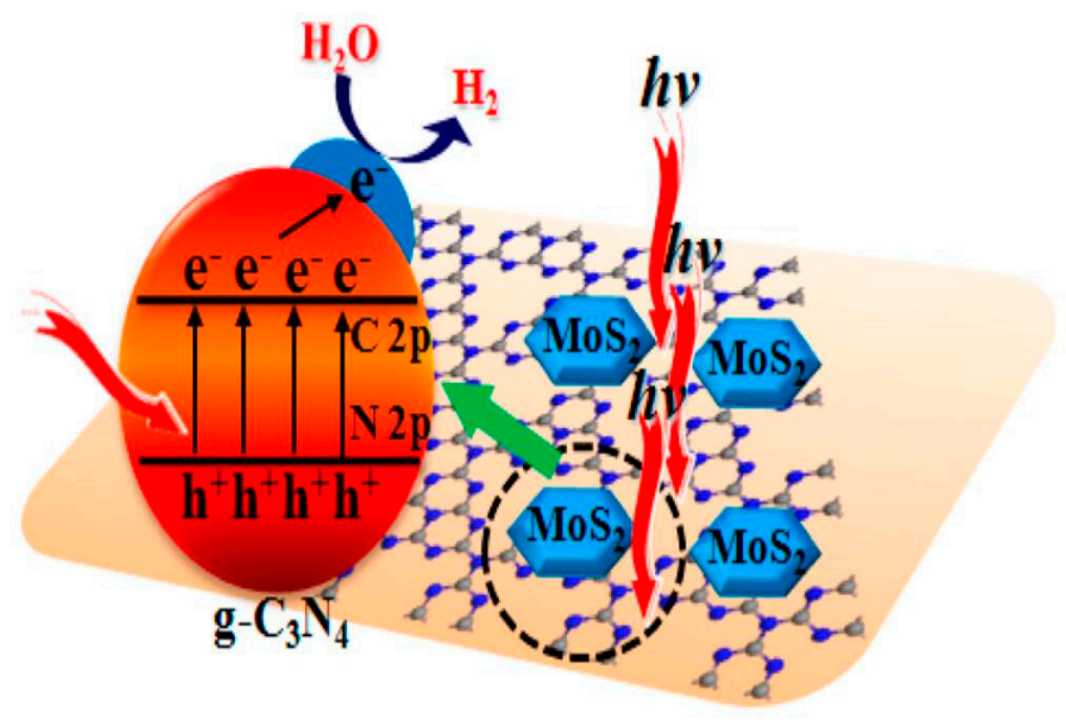

Figure 7. Schematic display of charge transfer on $\mathrm{MoS}_{2} / \mathrm{g}-\mathrm{C}_{3} \mathrm{~N}_{4}$ heterostructures during water splitting. Reproduced with permission from Reference [72]; copyright (2014), American Chemical Society.

\subsection{Metal-Loading-Based Photocatalysts}

Metal loading is also regarded as a useful method for photocatalytic enhancement. Song et al. [96] constructed Ag-rGO-TiO 2 composite photocatalysts (Figure 8) in 2018. In order to analyze the photocatalytic mechanism of the architectural $\mathrm{Ag}-\mathrm{TiO}_{2}$ and $\mathrm{Ag}-\mathrm{rGO}-\mathrm{TiO}_{2}$ composites, their structures with $\mathrm{Ag}$ nanocubes for light absorption and $\mathrm{TiO}_{2}$ nanosheets were well displayed. The difference 
between $\mathrm{Ag}-\mathrm{TiO}_{2}$ and $\mathrm{Ag}-\mathrm{rGO}-\mathrm{TiO}_{2}$ is the interface between $\mathrm{Ag}$ nanocubes and $\mathrm{TiO}_{2}$ nanosheets, which enhances the electron transfer capability. For $\mathrm{Ag}-\mathrm{TiO}_{2}$, the direct contact between the two materials results in the formation of $\mathrm{Ag}(100) /(001) \mathrm{TiO}_{2}$ interface. Meanwhile, for Ag-rGO-TiO both $\mathrm{Ag}(100) / \mathrm{rGO}$ and $\mathrm{rGO} /(001) \mathrm{TiO}_{2}$ interfaces are formed by rGO. As mentioned above, the synergistic effect of $\mathrm{Ag}(100) / \mathrm{rGO}$ and $\mathrm{rGO} /(001) \mathrm{TiO}_{2}$ interfaces, rather than the $\mathrm{Ag}(100) /(001) \mathrm{TiO}_{2}$ interface, offers quicker electron transfer. As shown in Figure 8, no Schottky barrier is formed between $\mathrm{Ag}$ and $\mathrm{TiO}_{2}$, and the hot electrons on the surface of $\mathrm{TiO}_{2}$ flow back to $\mathrm{Ag}$ and then recombine with holes. Meanwhile, for the Ag-rGO-TiO 2 sample, no barrier is necessary to facilitate the electron transfer. The electrons generated on the surface of $\mathrm{Ag}$ nanocubes with smaller work function flow to rGO via a contact so as to equilibrate the electron Fermi distribution on the interface $[97,98]$. Moreover, the rGO nanosheets can act as conductive channels, further transferring the electron to the $\mathrm{rGO} / \mathrm{TiO}_{2}$ interface. Owing to the light absorption of $\mathrm{rGO}$, the transferred electrons within the rGO nanosheets can be further transferred to the $\mathrm{CB}$ of $\mathrm{TiO}_{2}$ under light excitation. The proposed photocatalytic mechanism of $\mathrm{Ag}-\mathrm{rGO}-\mathrm{TiO}_{2}$ is illustrated in Figure 8.

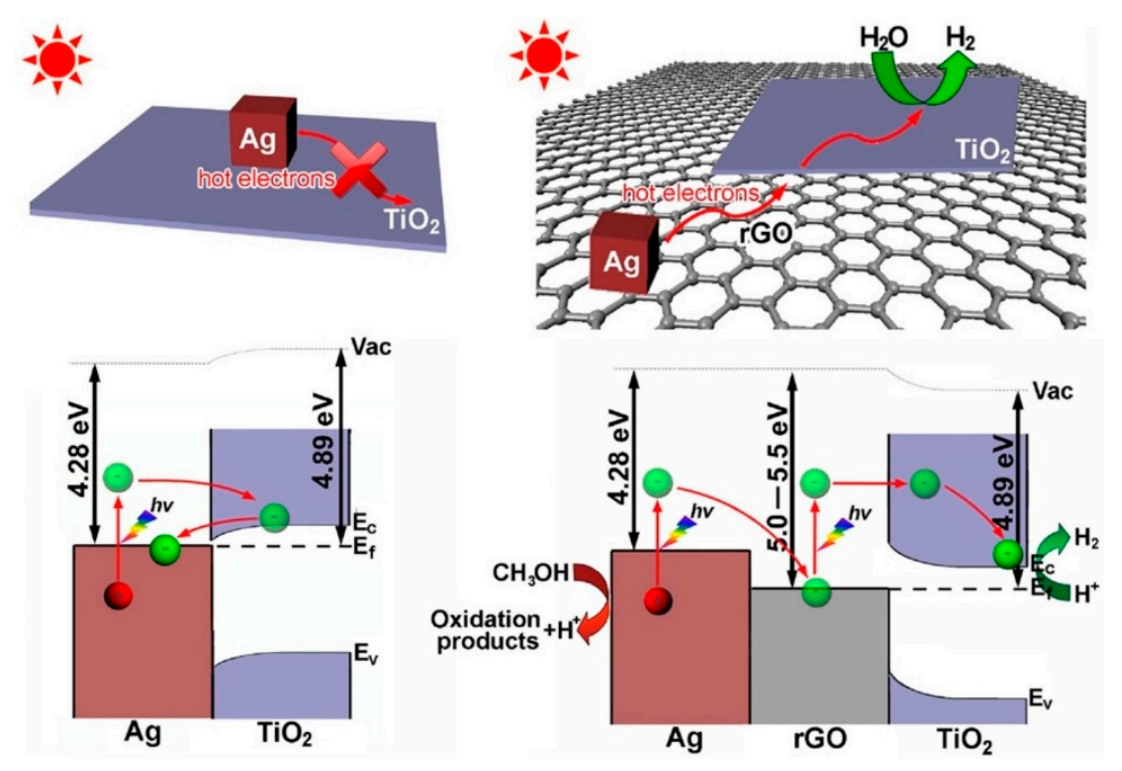

Figure 8. Schematic illustrating photocatalytic mechanism for $\mathrm{Ag}-\mathrm{TiO}_{2}$ and $\mathrm{Ag}-\mathrm{rGO}-\mathrm{TiO}_{2}$ samples under visible-light irradiation. Reproduced with permission from Reference [95]; copyright (2018), Elsevier.

\subsection{Z-Scheme Photocatalysts}

An illustration of Z-scheme water splitting is shown in Figure 9. During an $\mathrm{H}_{2}$ evolution reaction, the reactions which happen on the surface of photocatalysts include the reduction of protons by $\mathrm{CB}$ electrons and the oxidation of an electron donor (D) by VB holes, yielding the corresponding electron acceptor (A), as follows:

$$
\begin{gathered}
2 \mathrm{H}^{+}+2 e^{-} \rightarrow \mathrm{H}_{2} \quad\left(\text { photoreduction of } \mathrm{H}^{+} \text {to } \mathrm{H}_{2}\right) \\
D+n h^{+} \rightarrow A(\text { photooxidation of } D \text { to } A)
\end{gathered}
$$

On the other hand, the forward reactions on an $\mathrm{O}_{2}$ evolution photocatalyst are as follows:

$$
\begin{gathered}
A+n e^{-} \rightarrow D(\text { photoreduction of } A \text { to } D) \\
2 \mathrm{H}_{2} \mathrm{O}+4 h^{+} \rightarrow \mathrm{O}_{2}+4 \mathrm{H}^{+}\left(\left(\text {photooxidation of } \mathrm{H}_{2} \mathrm{O} \text { to } \mathrm{O}_{2}\right)\right.
\end{gathered}
$$


where the electron acceptor generated by the paired $\mathrm{H}_{2}$ evolution photocatalyst is converted to $\mathrm{D}$, and the water oxidation process occurs via the valence band holes. Thus, the water-splitting process can be achieved.

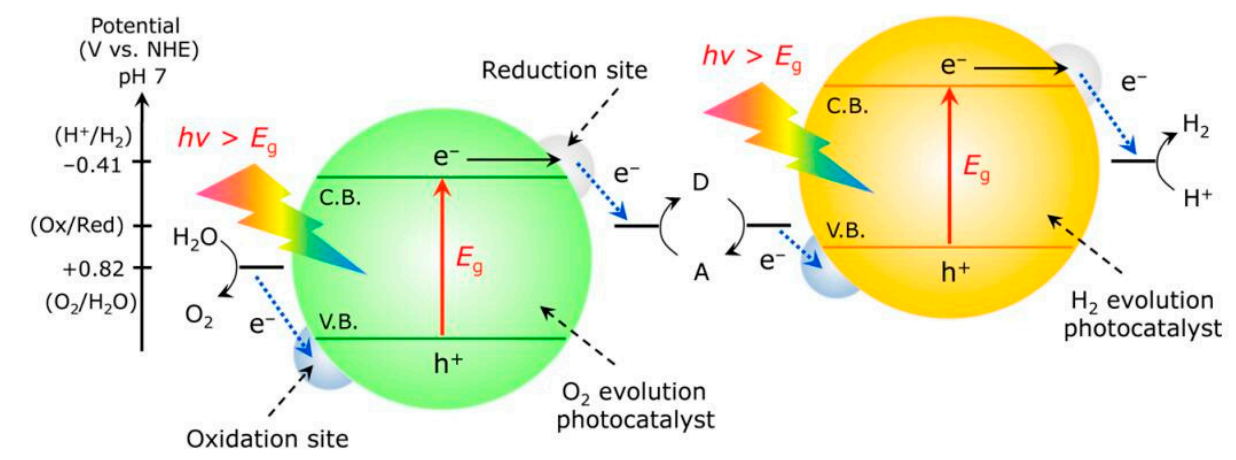

Figure 9. Diagram of photocatalytic water splitting using a Z-Scheme system. Reproduced with permission from Reference [98]; Copyright (2010), American Chemical Society.

Amal et al. reported a Z-scheme photocatalytic water-splitting system using $\mathrm{Ru} / \mathrm{SrTiO}_{3}$ and partially reduced GO (PRGO)/ $\mathrm{BiVO}_{4}$ (Figure 10) in 2011 [100]. As described in the report, the $\mathrm{PRGO} / \mathrm{BiVO}_{4}\left(\mathrm{O}_{2}\right.$ photocatalyst $)$ and $\mathrm{Ru} / \mathrm{SrTiO}_{3}: \mathrm{Rh}\left(\mathrm{H}_{2}\right.$ photocatalyst) were attached due to surface charge modification in acidic conditions, as depicted in Figure 10. Under irradiation, electrons are excited from the $\mathrm{VB}\left(\mathrm{BiVO}_{4}\right)$ or an impurity level in $\mathrm{Rh}\left(\mathrm{Ru} / \mathrm{SrTiO}_{3}: \mathrm{Rh}\right)$ to the $\mathrm{CB}$. We can indicate that the PRGO does not contribute to the electron and hole generation. In other words, the RGO in this work acts as an electron conductor. PRGO transfers the electrons from the $\mathrm{CB}$ of $\mathrm{BiVO}_{4}$ to the $\mathrm{Ru} / \mathrm{SrTiO}_{3}: \mathrm{Rh}$. Meanwhile, the electrons in $\mathrm{Ru} / \mathrm{SrTiO}_{3}: \mathrm{Rh}$ reduce the water to $\mathrm{H}_{2}$ on the surface of the $\mathrm{Ru}$ co-catalyst, while the holes left in $\mathrm{BiVO}_{4}$ oxidize the water to $\mathrm{O}_{2}$. Additionally, the PRGO provides a pathway for photogenerated electrons in the $\mathrm{BiVO}_{4}$ photocatalyst. Each reaction can migrate as follows: reduction of water, transfer of electrons to PRGO, and transfer of holes to PRGO for oxidation. Because the majority of the photocatalyst surface is surrounded by water and only relatively small portions are in contact with PRGO [101], most electrons in $\mathrm{Ru} / \mathrm{SrTiO}_{3}: \mathrm{Rh}$ and holes in $\mathrm{BiVO}_{4}$ are used for water splitting.

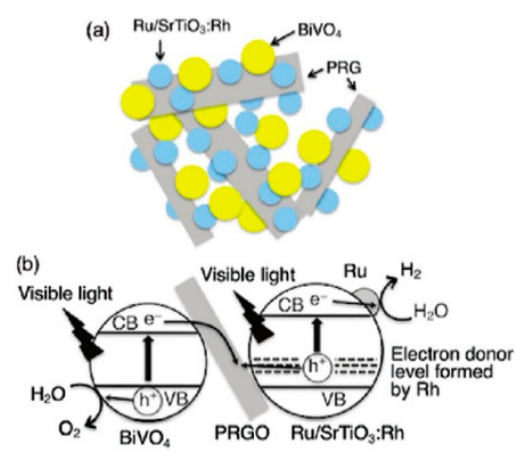

Figure 10. (a) Schematic display of a suspension of $\mathrm{Ru} / \mathrm{SrTiO}_{3}$ and partially reduced GO (PRGO) $/ \mathrm{BiVO}_{4}$ in water. (b) Mechanism of water splitting using Z-scheme system consisting of $\mathrm{Ru} / \mathrm{SrTiO}_{3}$ and $\mathrm{PRGO} / \mathrm{BiVO}_{4}$ under irradiation. Reproduced with permission from Reference [99]; copyright (2018), American Chemical Society.

\subsection{Defect Engineering Photocatalyst}

Among the various photocatalyst designs, the defect engineering strategy is regarded as an important way of modifying the photocatalysts. Defects are places where the atoms or molecules in the materials are disrupted, and they greatly influence photocatalytic performance. The defects in the lattice of photocatalysts not only act as an electron-hole recombination center, but also break 
the electronic structure and display a scattering center for electron and hole travel. Nevertheless, the positive effect of defects in photocatalytic performance enhancement were also recognized with the development of defect photocatalysts and the development of the photocatalytic field.

Chen et al. reported the synthesis of a bismuth subcarbonate $\left(\mathrm{Bi}_{2} \mathrm{O}_{2} \mathrm{CO}_{3}, \mathrm{BOC}\right)$ with controllable defect density (BOC-X) (Figure 11) in 2018. The BOC-X with defect density displayed a photocatalytic nitrogen fixation of $957 \mu \mathrm{mol} \cdot \mathrm{L}^{-1}$ under irradiation within $4 \mathrm{~h}$, which was 9.4 times higher than that of pristine BOC. This photocatalytic performance enhancement of BOC-X can be attributed to the surface defects. These defects contribute to the defect levels in the forbidden band, which improves the light harvest percentage. Meanwhile, surface defects can also inhibit the electron-hole recombination rate to promote the separation efficiency of charge carriers. Photocatalytic nitrogen fixation by BOC-X is displayed in Figure 11. If the light energy is higher than the band-gap energy, the electrons on the VB surface of BOC-X are transferred to the $\mathrm{CB}$ and react with $\mathrm{N}_{2}$ to form $\mathrm{NH}_{3}$. Moreover, some of the VB electrons are transferred to the defect level and then react with $\mathrm{N}_{2}$. However, if the light energy is lower than the band-gap energy, the electrons of BOC-X are also excited from VB to the defect level and then participate in the reaction. Defects modulate the band gap of BOC-X and improve the light absorption range, thereby enhancing the carrier transport, and leading to photocatalytic enhancement.

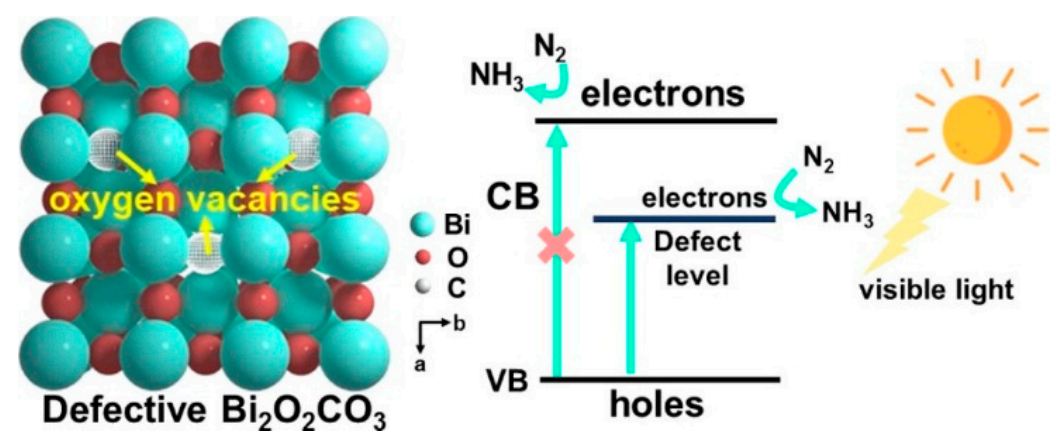

Figure 11. Mechanism of photocatalytic nitrogen fixation on defective $\mathrm{Bi}_{2} \mathrm{O}_{2} \mathrm{CO}_{3}$. Reproduced with permission from Reference [101]; copyright (2010), American Chemical Society.

\subsection{Heterojunction Photocatalysts}

During the $\mathrm{H}_{2}$ evolution reaction, the formed electron-hole charges are transferred to the surface of the photocatalyst for the next step of the reaction or recombine with each other [102-106]. To better reveal this point, we assumed it as a simple case [107]: the influence of gravity on a man jumping (Figure 12a,b). When a man (electron) jumps from the ground (VB) to the sky (CB), it can return to the floor immediately (recombination of the electron and hole) owing to gravity. In order to let the people rise off the floor (separation of the charge carrier pairs), an instrument (semiconductor B) can be used (Figure 12c,d). Subsequently, the previously mentioned people can drop to the instrument rather than the ground (inhibition of the electron and hole pair recombination). Although the inhibition of electron-hole recombination rate is an urgent issue, it can be achieved via suitable construction of materials. Many methods were conducted to achieve better electron-hole pair separation rate, such as element combining [108,109], metal doping [110,111], or the use of heterojunctions [112,113]. Among these strategies, heterojunctions were proven to be the most desirable method for achieving efficient photocatalysis due to their improved separation ability of electron-hole pairs (Figure 12d). 

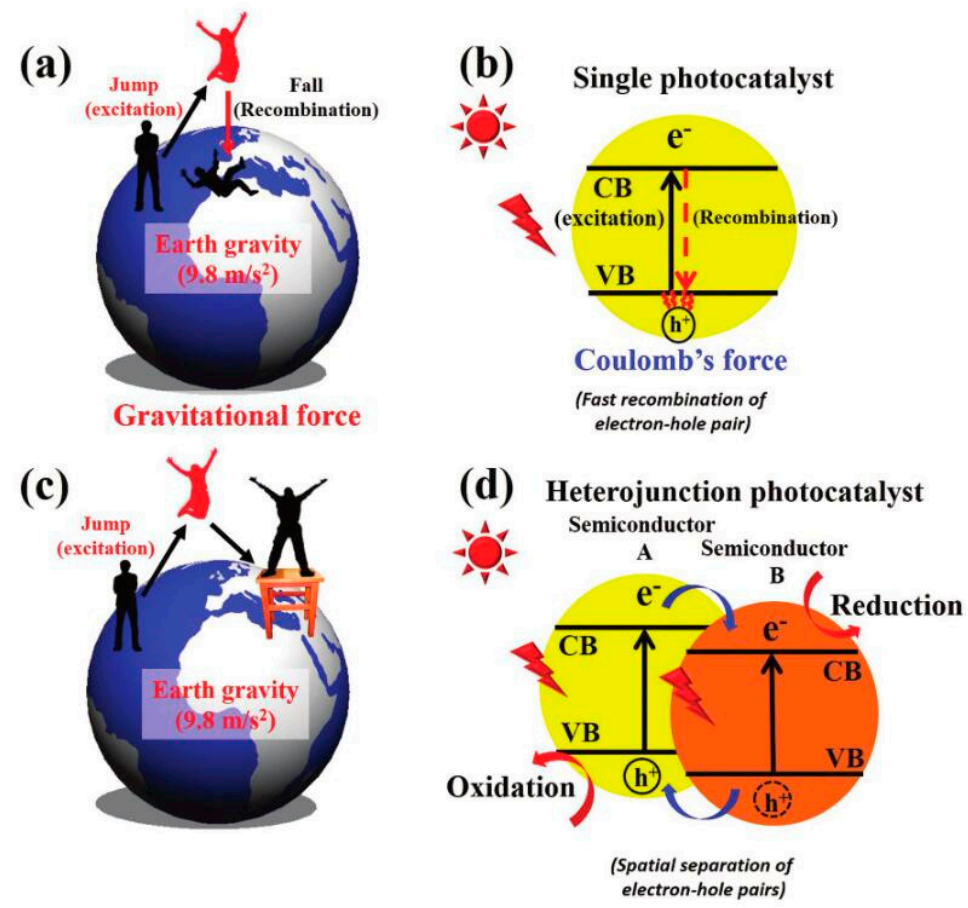

Figure 12. Schematic display of (a) the influence of gravity on a person jumping, (b) electron-hole pair combination using a photocatalyst, (c) utilization of a stool to keep the person from returning to the ground, (d) electron-hole pairs separated in composite catalyst. Reproduced with permission from Reference [105]; copyright (2010), John Wiley \& Sons, Inc.

A heterojunction is regarded as the connection between two kinds of photocatalysts with different band structures, which leads to a new band arrangement [114,115]. Generally, three kinds of composite photocatalysts are developed (Figure 13). As shown in Figure 13a, the CB and VB of A are a bit over and under the band position of $B$, respectively [116]. As a result, when the light irradiates, the generated electrons and holes are transferred to the CB and VB of $\mathrm{B}$. Because the generated electrons and holes move to the same photocatalyst, the recombination rate of electron-hole pairs is not efficiently inhibited. The photocatalytic process happens on photocatalyst $B$ with a mild potential requirement; thus, the photocatalytic ability of the photocatalyst using this heterojunction will be lower than others. As dispalyed in Figure 13b, the band positions of CB and VB are over that of photocatalyst $B$. Hence, during the photocatalytic reaction, the generated electron moves to photocatalyst $B$, while the holes are transferred to photocatalyst $\mathrm{A}$, which leads to the formation of long lived electron-hole pairs [117-119]. Parallel to Figure 13a, the photocatalytic performance of the type-II composite photocatalysts is inhibited by the redox process occurring on B. Meanwhile, as displayed in Figure 13c, the band structure of type-III composite photocatalysts is parallel to type II, apart from the interlaced gap changing into non-overlapping band gaps [120,121]. Thus, the generated electron-hole pairs cannot be transferred between the two photocatalysts, resulting in them being inappropriate for long lived electron-hole pair separation. We can determine that the type-II heterojunctions are desirable for enhancing redox ability due to their optimum structure for long-lived electron-hole separation. In previous reports, great efforts were conducted to synthesize type-II composite photocatalysts, including g- $\mathrm{C}_{3} \mathrm{~N}_{4} / \mathrm{TiO}_{2}$ [122], $\mathrm{WO}_{3} / \mathrm{BiVO}_{4}$ [123], $\mathrm{WO}_{3} / \mathrm{g}-\mathrm{C}_{3} \mathrm{~N}_{4}$ [124], and $\mathrm{BiPO}_{4} / \mathrm{g}-\mathrm{C}_{3} \mathrm{~N}_{4}$ [125]. 


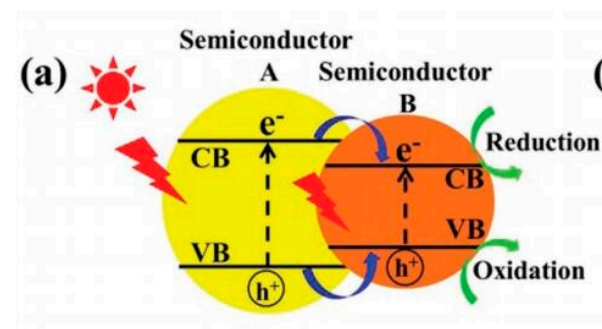

Straddling gap (type-I)

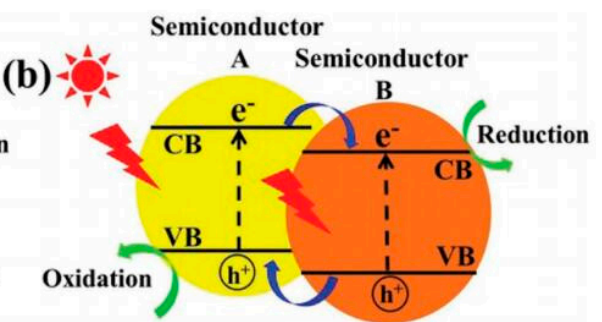

Staggered gap (type-II)

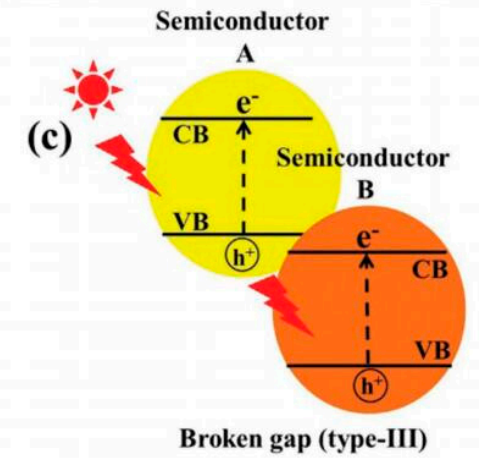

Figure 13. Schematic display of three kinds of electron-hole pair separation among composite photocatalysts: (a) type-I, (b) type-II, (c) type-III heterojunctions. Reproduced with permission from Reference [105]; copyright (2017), John Wiley \& Sons, Inc.

Yu et al. designed CdS/NiS composites photocatalysts using various heterojunctions in 2012, which greatly enhanced the hydrogen evolution performance. As shown in Figure 14a, around $20 \mathrm{~nm}$ of NiS particles were loaded onto the CdS uniformly, which supported a close connection between CdS and NiS. The formation of $\mathrm{p}-\mathrm{n}$ heterojunctions facilitates charge transfer between the NiS and CdS, and inhibits charge-carrier recombination (Figure 14b,c). We can see that the holes left on the n-type catalyst are transferred to the p-type catalyst, providing a negative specie. The electron-hole pair distribution keeps moving until a Fermi-level equilibrium is achieved [126-128]. The generated active species move through the internal electric field of the composite photocatalysts, resulting in long-lived electron-hole pair separation rates. Thus, the electron-hole recombination rate is efficiently inhibited owing to the synergistic effect between the two photocatalysts. The photocatalytic $\mathrm{H}_{2}$ production rate over CdS/NiS composite photocatalysts with $5 \mathrm{wt} . \% \mathrm{NiS}$ was found to be higher than that of the CdS and $1 \mathrm{wt} . \% \mathrm{Pt} / \mathrm{CdS}$ (Figure 14d). More NiS doping resulted in a reduction in photocatalytic efficiency due to NiS catalysts reducing the number of redox sites during the reaction. 

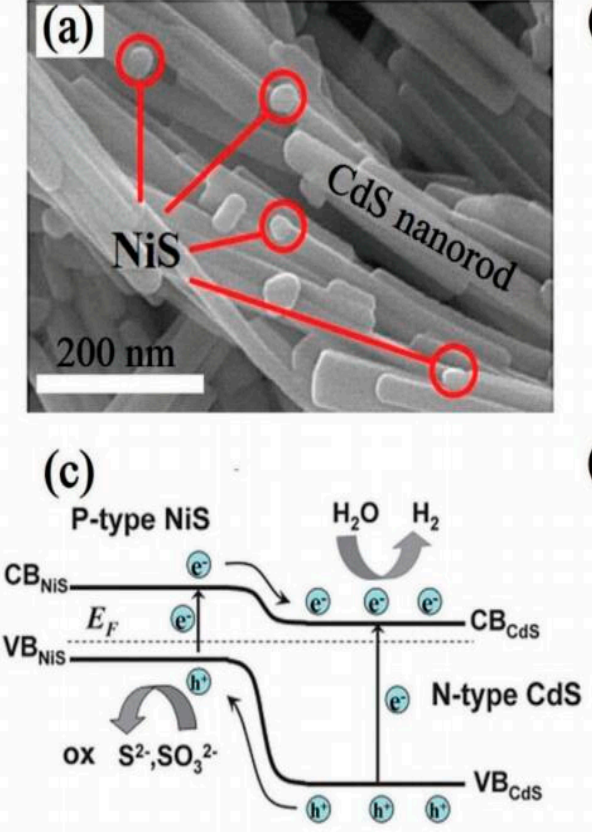

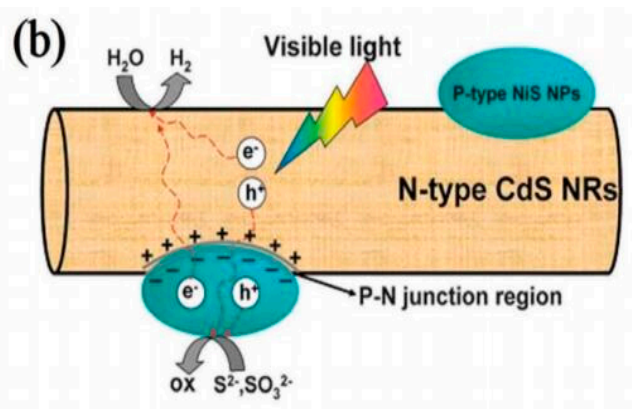

(d)

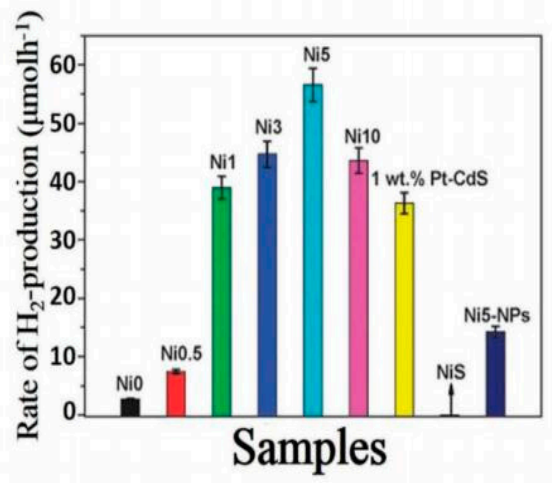

Figure 14. (a) SEM image of CdS/NiS composite catalysts; (b,c) illustration of electron-hole pairs with $\mathrm{CdS} / \mathrm{NiS}$ composite photocatalysts; (d) contrast of photocatalytic efficiency of CdS with different NiS content. Reproduced with permission from Reference [105]; copyright (2017), John Wiley \& Sons, Inc.

\section{Summary and Perspectives}

Over the last several decades, photocatalysis was shown to be a promising method for $\mathrm{H}_{2}$ production. Even though the principles controlling photocatalytic activity in the developed semiconductors were identified, several aspects remain unclear. Therefore, practical applications and the commercialization of photocatalytic $\mathrm{H}_{2}$ production require further research. Meanwhile, the charge transfer among photocatalysts due to the influence of structure and electrochemical properties is also not very clear, while the influence of various preparation methods on the catalytic performance is not well understood. The development of improved photocatalysts will benefit from advances in science. Improved building of novel co-catalysts will arise from using efficient catalysts. Many researches are underway investigating new synthesis methods for sample preparation and novel system construction. Herein, we concluded the most prominent achievements associated with $\mathrm{H}_{2}$ production via photocatalysis. We hope this report will assist further research efforts regarding the development of photocatalysts.

Funding: This research was supported by the Korea Evaluation Institute of Industrial Technology (KEIT) through the Carbon Cluster Construction project [10083586, Development of petroleum-based graphite fibers with ultra-high thermal conductivity] funded by the Ministry of Trade, Industry, \& Energy (MOTIE, Korea), and the Commercialization Promotion Agency for R\&D Outcomes (COMPA) funded by the Ministry of Science and ICT (MSIT) [2018_RND_002_0064, Development of $800 \mathrm{~mA} \cdot \mathrm{h} \cdot \mathrm{g}^{-1}$ pitch carbon coating materials].

Conflicts of Interest: The authors declare no conflict of interest.

\section{References}

1. Park, S.J.; Lee, S.Y. A study on hydrogen-storage behaviors of nickel-loaded mesoporous MCM-41. J. Colloid Interface Sci. 2010, 346, 194-198. [CrossRef] [PubMed]

2. Catapan, R.C.; Cancino, L.R.; Oliveira, A.A.M.; Schwarz, C.O.; Nitschke, H.; Frank, T. Potential for onboard hydrogen production in an direct injection ethanol fueled spark ignition engine with EGR. Fuel 2018, 234, 441-446. [CrossRef] 
3. Im, J.S.; Park, S.-J.; Kim, T.; Lee, Y.-S. Hydrogen storage evaluation based on investigations of the catalyticproperties of metal/metal oxides in electrospun carbon fibers. Int. J. Hydrogen Energy 2009, 34, 3382-3388. [CrossRef]

4. Park, S.-J.; Lee, S.-Y. Hydrogen storage behaviors of platinum-supported multi-walled carbon nanotubes. Int. J. Hydrogen Energy 2010, 35, 13048-13054. [CrossRef]

5. Lee, S.-Y.; Park, S.-J. Effect of platinum doping of activated carbon on hydrogen storage behaviors of metal-organic frameworks-5. Int. J. Hydrogen Energy 2011, 36, 8381-8387. [CrossRef]

6. Baykara, S.Z. Hydrogen: A brief overview on its sources, production and environmental impact. Int. J. Hydrogen Energy 2018, 43, 10605-10614. [CrossRef]

7. Chen, M.; Cui, W.; Zhu, K.; Xie, Y.; Zhang, C.; Shen, W. Hydrogen-rich water alleviates aluminum-induced inhibition of root elongation in alfalfa via decreasing nitric oxide production. J. Hazard. Mater. 2014, 267, 40-47. [CrossRef] [PubMed]

8. Cui, W.; Gao, C.; Fang, P.; Lin, G.; Shen, W. Alleviation of cadmium toxicity in Medicago sativa by hydrogen-rich water. J. Hazard. Mater. 2013, 260, 715-724. [CrossRef] [PubMed]

9. Gao, Q.; Song, H.; Wang, X.T.; Liang, Y.; Xi, Y.J.; Gao, Y.; Guo, Q.J.; LeBaron, T.; Luo, Y.X.; Li, S.C.; et al. Molecular hydrogen increases resilience to stress in mice. Sci. Rep. 2017, 7, 9625. [CrossRef]

10. Giuliani, D.; Ottani, A.; Zaffe, D.; Galantucci, M.; Strinati, F.; Lodi, R.; Guarini, S. Hydrogen sulfide slows down progression of experimental Alzheimer's disease by targeting multiple pathophysiological mechanisms. Neurobiol. Learn. Mem. 2013, 104, 82-91. [CrossRef]

11. Huang, C.S.; Kawamura, T.; Toyoda, Y.; Nakao, A. Recent advances in hydrogen research as a therapeutic medical gas. Free Radic. Res. 2010, 44, 971-982. [CrossRef] [PubMed]

12. Kumar, R.; Kumar, A.; Langstrom, B.; Darreh-Shori, T. Discovery of novel choline acetyltransferase inhibitors using structure-based virtual screening. Sci. Rep. 2017, 7, 16287. [CrossRef]

13. Li, J.; Wang, C.; Zhang, J.H.; Cai, J.M.; Cao, Y.P.; Sun, X.J. Hydrogen-rich saline improves memory function in a rat model of amyloid-beta-induced Alzheimer's disease by reduction of oxidative stress. Brain Res. 2010, 1328, 152-161. [CrossRef]

14. Luo, Q.; Lin, Y.X.; Yang, P.P.; Wang, Y.; Qi, G.B.; Qiao, Z.Y.; Li, B.N.; Zhang, K.; Zhang, J.P.; Wang, L.; et al. A self-destructive nanosweeper that captures and clears amyloid beta-peptides. Nat. Commun. 2018, 9, 1802. [CrossRef] [PubMed]

15. Nagata, K.; Nakashima-Kamimura, N.; Mikami, T.; Ohsawa, I.; Ohta, S. Consumption of molecular hydrogen prevents the stress-induced impairments in hippocampus-dependent learning tasks during chronic physical restraint in mice. Neuropsychopharmacol. Off. Publ. Am. Coll. Neuropsychopharmacol. 2009, 34, 501-508. [CrossRef]

16. Nakayama, M.; Itami, N.; Suzuki, H.; Hamada, H.; Yamamoto, R.; Tsunoda, K.; Osaka, N.; Nakano, H.; Maruyama, Y.; Kabayama, S.; et al. Novel haemodialysis (HD) treatment employing molecular hydrogen (H2)-enriched dialysis solution improves prognosis of chronic dialysis patients: A prospective observational study. Sci. Rep. 2018, 8, 254. [CrossRef] [PubMed]

17. Nishimaki, K.; Asada, T.; Ohsawa, I.; Nakajima, E.; Ikejima, C.; Yokota, T.; Kamimura, N.; Ohta, S. Effects of Molecular Hydrogen Assessed by an Animal Model and a Randomized Clinical Study on Mild Cognitive Impairment. Curr. Alzheimer Res. 2018, 15, 482-492. [CrossRef] [PubMed]

18. Ohsawa, I.; Ishikawa, M.; Takahashi, K.; Watanabe, M.; Nishimaki, K.; Yamagata, K.; Katsura, K.; Katayama, Y.; Asoh, S.; Ohta, S. Hydrogen acts as a therapeutic antioxidant by selectively reducing cytotoxic oxygen radicals. Nat. Med. 2007, 13, 688-694. [CrossRef]

19. Xiao, H.W.; Li, Y.; Luo, D.; Dong, J.L.; Zhou, L.X.; Zhao, S.Y.; Zheng, Q.S.; Wang, H.C.; Cui, M.; Fan, S.J. Hydrogen-water ameliorates radiation-induced gastrointestinal toxicity via MyD88's effects on the gut microbiota. Exp. Mol. Med. 2018, 50, e433. [CrossRef]

20. Zhang, L.M.; Jiang, C.X.; Liu, D.W. Hydrogen sulfide attenuates neuronal injury induced by vascular dementia via inhibiting apoptosis in rats. Neurochem. Res. 2009, 34, 1984-1992. [CrossRef] [PubMed]

21. Zhang, Y.; Su, W.J.; Chen, Y.; Wu, T.Y.; Gong, H.; Shen, X.L.; Wang, Y.X.; Sun, X.J.; Jiang, C.L. Effects of hydrogen-rich water on depressive-like behavior in mice. Sci. Rep. 2016, 6, 23742. [CrossRef] [PubMed]

22. Liu, S.; Xin, Z.-J.; Lei, Y.-J.; Yang, Y.; Yan, X.-Y.; Lu, Y.-B.; Li, C.-B.; Wang, H.-Y. Thin Copper-Based Film for Efficient Electrochemical Hydrogen Production from Neutral Aqueous Solutions. ACS Sustain. Chem. Eng. 2017, 5, 7496-7501. [CrossRef] 
23. Wang, Z.; Yang, X.; Yang, T.; Zhao, Y.; Wang, F.; Chen, Y.; Zeng, J.H.; Yan, C.; Huang, F.; Jiang, J.-X. Dibenzothiophene Dioxide Based Conjugated Microporous Polymers for Visible-Light-Driven Hydrogen Production. ACS Catal. 2018, 8, 8590-8596. [CrossRef]

24. Zhu, K.; Kang, S.-Z.; Qin, L.; Han, S.; Li, G.; Li, X. Novel and Highly Active Potassium Niobate-Based Photocatalyst for Dramatically Enhanced Hydrogen Production. J. Am. Chem. Soc. 2005, 127, 11447-11453. [CrossRef]

25. Hibino, T.; Kobayashi, K.; Ito, M.; Ma, Q.; Nagao, M.; Fukui, M.; Teranishi, S. Kinetics of the Interconversion of Parahydrogen and Orthohydrogen Catalyzed by Paramagnetic Complex Ions. J. Am. Chem. Soc. 2005, 127, 11447-11453.

26. Fujishima, A.; Honda, K. Electrochemical Photolysis of Water at a Semiconductor Electrode. Nature 1972, 238, 37-38. [CrossRef] [PubMed]

27. Zhang, P.; Song, T.; Wang, T.; Zeng, H. In-situ synthesis of Cu nanoparticles hybridized with carbon quantum dots as a broad spectrum photocatalyst for improvement of photocatalytic $\mathrm{H}_{2}$ evolution. Appl. Catal. B Environ. 2017, 206, 328-335. [CrossRef]

28. Zhang, P.; Song, T.; Wang, T.; Zeng, H. Plasmonic Cu nanoparticle on reduced graphene oxide nanosheet support: An efficient photocatalyst for improvement of near-infrared photocatalytic $\mathrm{H}_{2}$ evolution. Appl. Catal. B Environ. 2018, 225, 172-179. [CrossRef]

29. Zhang, P.; Wang, T.; Zeng, H. Design of $\mathrm{Cu}-\mathrm{Cu}_{2} \mathrm{O} / \mathrm{g}-\mathrm{C}_{3} \mathrm{~N}_{4}$ nanocomponent photocatalysts for hydrogen evolution under visible light irradiation using water-soluble Erythrosin B dye sensitization. Appl. Surf. Sci. 2017, 391, 404-414. [CrossRef]

30. Zhang, P.; Song, T.; Wang, T.; Zeng, H. Effectively extending visible light absorption with a broad spectrum sensitizer for improving the $\mathrm{H}_{2}$ evolution of in-situ $\mathrm{Cu} / \mathrm{g}-\mathrm{C}_{3} \mathrm{~N}_{4}$ nanocomponents. Int. J. Hydrogen Energy 2017, 42, 14511-14521. [CrossRef]

31. Zhang, Y.; Park, M.; Kim, H.Y.; Ding, B.; Park, S.J. A facile ultrasonic-assisted fabrication of nitrogen-doped carbon dots $/ \mathrm{BiOBr}$ up-conversion nanocomposites for visible light photocatalytic enhancements. Sci. Rep. 2017, 7, 45086. [CrossRef] [PubMed]

32. Zhang, Y.; Park, S.-J. Bimetallic AuPd alloy nanoparticles deposited on $\mathrm{MoO}_{3}$ nanowires for enhanced visible-light driven trichloroethylene degradation. J. Catal. 2018, 361, 238-247. [CrossRef]

33. Zhang, Y.; Park, S.-J. Au-pd bimetallic alloy nanoparticle-decorated $\mathrm{BiPO}_{4}$ nanorods for enhanced photocatalytic oxidation of trichloroethylene. J. Catal. 2017, 355, 1-10. [CrossRef]

34. Yu, H.; Xue, Y.; Hui, L.; Zhang, C.; Li, Y.; Zuo, Z.; Zhao, Y.; Li, Z.; Li, Y. Efficient Hydrogen Production on a 3D Flexible Heterojunction Material. Adv. Mater. 2018, 30, e1707082. [CrossRef]

35. Zhang, P.; Song, T.; Wang, T.; Zeng, H. Fabrication of a non-semiconductor photocatalytic system using dendrite-like plasmonic $\mathrm{CuNi}$ bimetal combined with a reduced graphene oxide nanosheet for near-infrared photocatalytic $\mathrm{H}_{2}$ evolution. J. Mater. Chem. A 2017, 5, 22772-22781. [CrossRef]

36. Lin, L.; Ren, W.; Wang, C.; Asiri, A.M.; Zhang, J.; Wang, X. Crystalline carbon nitride semiconductors prepared at different temperatures for photocatalytic hydrogen production. Appl. Catal. B Environ. 2018, 231, 234-241. [CrossRef]

37. Im, J.S.; Kwon, O.; Kim, Y.H.; Park, S.-J.; Lee, Y.-S. The effect of embedded vanadium catalyst on activated electrospun CFs for hydrogen storage. Microporous Mesoporous Mater. 2008, 115, 514-521. [CrossRef]

38. Yi, H.; Huang, D.; Qin, L.; Zeng, G.; Lai, C.; Cheng, M.; Ye, S.; Song, B.; Ren, X.; Guo, X. Selective prepared carbon nanomaterials for advanced photocatalytic application in environmental pollutant treatment and hydrogen production. Appl. Catal. B Environ. 2018, 239, 408-424. [CrossRef]

39. Ismail, A.A.; Bahnemann, D.W. Photochemical splitting of water for hydrogen production by photocatalysis: A review. Sol. Energy Mater. Sol. Cells 2014, 128, 85-101. [CrossRef]

40. Cai, J.; Shen, J.; Zhang, X.; Ng, Y.H.; Huang, J.; Guo, W.; Lin, C.; Lai, Y. Light-Driven Sustainable Hydrogen Production Utilizing $\mathrm{TiO}_{2}$ Nanostructures: A Review. Small Methods 2018, 1800184. [CrossRef]

41. Ventura-Espinosa, D.; Sabater, S.; Carretero-Cerdán, A.; Baya, M.; Mata, J.A. High Production of Hydrogen on Demand from Silanes Catalyzed by Iridium Complexes as a Versatile Hydrogen Storage System. ACS Catal. 2018, 8, 2558-2566. [CrossRef]

42. Ji, L.; Lv, C.; Chen, Z.; Huang, Z.; Zhang, C. Nickel-Based (Photo) Electrocatalysts for Hydrogen Production. Adv. Mater. 2018, 30, e1705653. [CrossRef] [PubMed] 
43. Ma, Y.; Dong, X.; Wang, Y.; Xia, Y. Decoupling Hydrogen and Oxygen Production in Acidic Water Electrolysis Using a Polytriphenylamine-Based Battery Electrode. Angewandte Chem. 2018, 57, 2904-2908. [CrossRef] [PubMed]

44. Wang, B.; Zeng, C.; Chu, K.H.; Wu, D.; Yip, H.Y.; Ye, L.; Wong, P.K. Enhanced Biological Hydrogen Production from Escherichia coli with Surface Precipitated Cadmium Sulfide Nanoparticles. Adv. Energy Mater. 2017, 7, 1700611. [CrossRef]

45. Xue, Z.; Shen, Y.; Li, P.; Zhang, Y.; Li, J.; Qin, B.; Zhang, J.; Zeng, Y.; Zhu, S. Key Role of Lanthanum Oxychloride: Promotional Effects of Lanthanum in NiLaOy/ NaCl for Hydrogen Production from Ethyl Acetate and Water. Small 2018, 14, e1800927. [CrossRef] [PubMed]

46. Zhang, Y.; Yang, H.M.; Park, S.-J. Synthesis and characterization of nitrogen-doped $\mathrm{TiO}_{2}$ coatings on reduced graphene oxide for enhancing the visible light photocatalytic activity. Curr. Appl. Phys. 2018, 18, 163-169. [CrossRef]

47. Zhang, Y.; Park, M.; Kim, H.-Y.; Park, S.-J. In-situ synthesis of graphene oxide/BiOCl heterostructured nanofibers for visible-light photocatalytic investigation. J. Alloy Compd. 2016, 686, 106-114. [CrossRef]

48. Huang, J.; Li, G.; Zhou, Z.; Jiang, Y.; Hu, Q.; Xue, C.; Guo, W. Efficient photocatalytic hydrogen production over $\mathrm{Rh}$ and $\mathrm{Nb}$ codoped $\mathrm{TiO}_{2}$ nanorods. Chem. Eng. J. 2018, 337, 282-289. [CrossRef]

49. Kim, W.; Monllor-Satoca, D.; Chae, W.-S.; Mahadik, M.A.; Jang, J.S. Enhanced photoelectrochemical and hydrogen production activity of aligned CdS nanowire with anisotropic transport properties. Appl. Surf. Sci. 2019, 463, 339-347. [CrossRef]

50. Han, J.; Liu, Y.; Dai, F.; Zhao, R.; Wang, L. Fabrication of $\mathrm{CdSe} / \mathrm{CaTiO}_{3}$ nanocomposties in aqueous solution for improved photocatalytic hydrogen production. Appl. Surf. Sci. 2018, 459, 520-526. [CrossRef]

51. Zhang, Y.; Park, M.; Kim, H.Y.; Ding, B.; Park, S.-J. In-situ synthesis of nanofibers with various ratios of $\mathrm{BiOClx} / \mathrm{BiOBry} / \mathrm{BiOIz}$ for effective trichloroethylene photocatalytic degradation. Appl. Surf. Sci. 2016, 384, 192-199. [CrossRef]

52. Pipitone, G.; Tosches, D.; Bensaid, S.; Galia, A.; Pirone, R. Valorization of alginate for the production of hydrogen via catalytic aqueous phase reforming. Catal. Today 2018, 304, 153-164. [CrossRef]

53. Hibino, T.; Kobayashi, K.; Ito, M.; Nagao, M.; Fukui, M.; Teranishi, S. Direct electrolysis of waste newspaper for sustainable hydrogen production: An oxygen-functionalized porous carbon anode. Appl. Catal. B Environ. 2018, 231, 191-199. [CrossRef]

54. Park, S.; Kim, B.; Lee, Y.; Cho, M. Influence of copper electroplating on high pressure hydrogen-storage behaviors of activated carbon fibers. Int. J. Hydrogen Energy 2008, 33, 1706-1710. [CrossRef]

55. Im, J.S.; Park, S.-J.; Lee, Y.-S. Superior prospect of chemically activated electrospun carbon fibers for hydrogen storage. Mater. Res. Bull. 2009, 44, 1871-1878. [CrossRef]

56. Xiang, Q.; Yu, J. Graphene-Based Photocatalysts for Hydrogen Generation. J. Phys. Chem. Lett. 2013, 4, 753-759. [CrossRef]

57. Kim, H.-I.; Moon, G.-H.; Monllor-Satoca, D.; Park, Y.; Choi, W. Solar Photoconversion Using Graphene/TiO 2 Composites: Nanographene Shell on $\mathrm{TiO}_{2}$ Core versus $\mathrm{TiO}_{2}$ Nanoparticles on Graphene Sheet. J. Phys. Chem. C 2011, 116, 1535-1543. [CrossRef]

58. Wu, Z.; Zhou, Z.; Zhang, Y.; Wang, J.; Shi, H.; Shen, Q.; Wei, G.; Zhao, G. Simultaneous photoelectrocatalytic aromatic organic pollutants oxidation for hydrogen production promotion with a self-biasing photoelectrochemical cell. Électrochim. Acta 2017, 254, 140-147. [CrossRef]

59. Kim, B.J.; Lee, Y.S.; Park, S.J. Preparation of platinum-decorated porous graphite nanofibers, and their hydrogen storage behaviors. J. Colloid Interface Sci. 2008, 318, 530-533. [CrossRef]

60. Zhang, Y.; Park, S.-J. Fabrication and characterization of flower-like BiOI/Pt heterostructure with enhanced photocatalytic activity under visible light irradiation. J. Solid State Chem. 2017, 253, 421-429. [CrossRef]

61. Zhang, Y.; Park, S.-J. Incorporation of $\mathrm{RuO}_{2}$ into charcoal-derived carbon with controllable microporosity by $\mathrm{CO}_{2}$ activation for high-performance supercapacitor. Carbon 2017, 122, 287-297. [CrossRef]

62. Panthi, G.; Park, M.; Kim, H.-Y.; Park, S.-J. Electrospun polymeric nanofibers encapsulated with nanostructured materials and their applications: A review. J. Ind. Eng. Chem. 2015, 24, 1-13. [CrossRef]

63. Panthi, G.; Park, M.; Kim, H.-Y.; Lee, S.-Y.; Park, S.-J. Electrospun ZnO hybrid nanofibers for photodegradation of wastewater containing organic dyes: A review. J. Ind. Eng. Chem. 2015, 21, 26-35. [CrossRef] 
64. Kim, S.; Park, S. Electroactivity of $\mathrm{Pt}-\mathrm{Ru} /$ polyaniline composite catalyst-electrodes prepared by electrochemical deposition methods. Solid State Ion. 2008, 178, 1915-1921. [CrossRef]

65. Park, S.J.; Kim, B.J. Influence of oxygen plasma treatment on hydrogen chloride removal of activated carbon fibers. J. Colloid Interface Sci. 2004, 275, 590-595. [CrossRef] [PubMed]

66. Park, S.-J.; Kim, J.S. Modifications produced by electrochemical treatments oncarbon blacks Microstructures and mechanical interfacial properties. Carbon 2001, 39, 2011-2016. [CrossRef]

67. Chen, W.-T.; Chan, A.; Sun-Waterhouse, D.; Llorca, J.; Idriss, H.; Waterhouse, G.I.N. Performance comparison of $\mathrm{Ni} / \mathrm{TiO}_{2}$ and $\mathrm{Au} / \mathrm{TiO}_{2}$ photocatalysts for $\mathrm{H}_{2}$ production in different alcohol-water mixtures. J. Catal. 2018, 367, 27-42. [CrossRef]

68. Hou, H.; Liu, H.; Gao, F.; Shang, M.; Wang, L.; Xu, L.; Wong, W.-Y.; Yang, W. Packaging BiVO $_{4}$ nanoparticles in $\mathrm{ZnO}$ microbelts for efficient photoelectrochemical hydrogen production. Electrochim. Acta 2018, 283, 497-508. [CrossRef]

69. Belhadj, H.; Hamid, S.; Robertson, P.K.J.; Bahnemann, D.W. Mechanisms of Simultaneous Hydrogen Production and Formaldehyde Oxidation in $\mathrm{H}_{2} \mathrm{O}$ and $\mathrm{D}_{2} \mathrm{O}$ over Platinized $\mathrm{TiO}_{2}$. ACS Catal. 2017, 7, 4753-4758. [CrossRef]

70. Akbarzadeh, R.; Ghaedi, M.; Nasiri Kokhdan, S.; Jannesar, R.; Sadeghfar, F.; Sadri, F.; Tayebi, L. Electrochemical hydrogen storage, photocatalytical and antibacterial activity of $\mathrm{Fe} \mathrm{Ag}$ bimetallic nanoparticles supported on $\mathrm{TiO}_{2}$ nanowires. Int. J. Hydrogen Energy 2018, 43, 18316-18329. [CrossRef]

71. Chen, C.; Cai, W.M.; Long, M.C.; Zhou, B.X.; Wu, Y.H.; Wu, D.Y.; Feng, Y.J. Synthesis of Visible Light Responsive Graphene Oxide/ $\mathrm{TiO}_{2}$ Composites with p/n Heterojunction. ACS Nano 2010, 4, 6425-6432. [CrossRef] [PubMed]

72. Cao, S.; Yu, J. g-C $\mathrm{C}_{3} \mathrm{~N}_{4}$-Based Photocatalysts for Hydrogen Generation. J. Phys. Chem. Lett. 2014, 5, $2101-2107$. [CrossRef] [PubMed]

73. Rather, R.A.; Singh, S.; Pal, B. A $\mathrm{C}_{3} \mathrm{~N}_{4}$ surface passivated highly photoactive $\mathrm{Au}-\mathrm{TiO}_{2}$ tubular nanostructure for the efficient $\mathrm{H}_{2}$ production from water under sunlight irradiation. Appl. Catal. B Environ. 2017, 213, 9-17. [CrossRef]

74. Bian, H.; Ji, Y.; Yan, J.; Li, P.; Li, L.; Li, Y.; Frank Liu, S. In Situ Synthesis of Few-Layered g-C ${ }_{3} \mathrm{~N}_{4}$ with Vertically Aligned $\mathrm{MoS}_{2}$ Loading for Boosting Solar-to-Hydrogen Generation. Small 2018, 14, 1703003. [CrossRef] [PubMed]

75. Tian, N.; Zhang, Y.; Li, X.; Xiao, K.; Du, X.; Dong, F.; Waterhouse, G.I.N.; Zhang, T.; Huang, H. Precursor-reforming protocol to $3 \mathrm{D}$ mesoporous $\mathrm{g}-\mathrm{C}_{3} \mathrm{~N}_{4}$ established by ultrathin self-doped nanosheets for superior hydrogen evolution. Nano Energy 2017, 38, 72-81. [CrossRef]

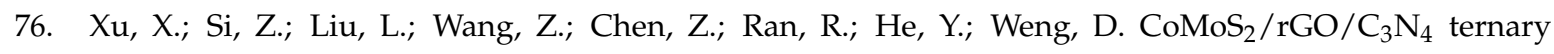
heterojunctions catalysts with high photocatalytic activity and stability for hydrogen evolution under visible light irradiation. Appl. Surf. Sci. 2018, 435, 1296-1306. [CrossRef]

77. Luo, X.; Wu, Z.; Liu, Y.; Ding, S.; Zheng, Y.; Jiang, Q.; Zhou, T.; Hu, J. Engineering Amorphous Carbon onto Ultrathin $\mathrm{g}-\mathrm{C}_{3} \mathrm{~N}_{4}$ to Suppress Intersystem Crossing for Efficient Photocatalytic $\mathrm{H}_{2}$ Evolution. Adv. Mater. Interfaces 2018, 5, 1800859. [CrossRef]

78. Wang, Y.; Wang, X.; Antonietti, M. Polymeric graphitic carbon nitride as a heterogeneous organocatalyst: From photochemistry to multipurpose catalysis to sustainable chemistry. Angewandte Chem. 2012, 51, 68-89. [CrossRef]

79. Wang, X.; Maeda, K.; Thomas, A.; Takanabe, K.; Xin, G.; Carlsson, J.M.; Domen, K.; Antonietti, M. A metal-free polymeric photocatalyst for hydrogen production from water under visible light. Nat. Mater. 2009, 8, 76-80. [CrossRef]

80. Gao, H.; Yang, H.; Xu, J.; Zhang, S.; Li, J. Strongly Coupled g- $\mathrm{C}_{3} \mathrm{~N}_{4}$ Nanosheets- $\mathrm{Co}_{3} \mathrm{O}_{4}$ Quantum Dots as 2D/0D Heterostructure Composite for Peroxymonosulfate Activation. Small 2018, 14, 1801353. [CrossRef]

81. Chen, Z.; Xia, K.; She, X.; Mo, Z.; Zhao, S.; Yi, J.; Xu, Y.; Chen, H.; Xu, H.; Li, H. $1 \mathrm{D}$ metallic $\mathrm{MoO}_{2}-\mathrm{C}$ as co-catalyst on $2 \mathrm{D} \mathrm{g}-\mathrm{C}_{3} \mathrm{~N}_{4}$ semiconductor to promote photocatlaytic hydrogen production. Appl. Surf. Sci. 2018, 447, 732-739. [CrossRef]

82. Kong, L.; Ji, Y.; Dang, Z.; Yan, J.; Li, P.; Li, Y.; Liu, S.F. g- $\mathrm{C}_{3} \mathrm{~N}_{4}$ Loading Black Phosphorus Quantum Dot for Efficient and Stable Photocatalytic H2 Generation under Visible Light. Adv. Funct. Mater. 2018, 28, 1800668. [CrossRef] 
83. Wan, J.; Pu, C.; Wang, R.; Liu, E.; Du, X.; Bai, X.; Fan, J.; Hu, X. A facile dissolution strategy facilitated by $\mathrm{H}_{2} \mathrm{SO}_{4}$ to fabricate a $2 \mathrm{D}$ metal-free g- $\mathrm{C}_{3} \mathrm{~N}_{4} / \mathrm{rGO}$ heterojunction for efficient photocatalytic $\mathrm{H}_{2}$ production. Int. J. Hydrogen Energy 2018, 43, 7007-7019. [CrossRef]

84. Marcì, G.; García-López, E.I.; Palmisano, L. Polymeric carbon nitride $\left(\mathrm{C}_{3} \mathrm{~N}_{4}\right)$ as heterogeneous photocatalyst for selective oxidation of alcohols to aldehydes. Catal. Today 2018, 315, 126-137. [CrossRef]

85. Oh, W.-D.; Lok, L.-W.; Veksha, A.; Giannis, A.; Lim, T.-T. Enhanced photocatalytic degradation of bisphenol A with Ag-decorated S-doped g- $\mathrm{C}_{3} \mathrm{~N}_{4}$ under solar irradiation: Performance and mechanistic studies. Chem. Eng. J. 2018, 333, 739-749. [CrossRef]

86. Hou, Y.; Laursen, A.B.; Zhang, J.; Zhang, G.; Zhu, Y.; Wang, X.; Dahl, S.; Chorkendorff, I. Layered nanojunctions for hydrogen-evolution catalysis. Angewandte Chem. 2013, 52, 3621-3625. [CrossRef] [PubMed]

87. Zhou, J.; Zhao, Y.; Bao, J.; Huo, D.; Fa, H.; Shen, X.; Hou, C. One-step electrodeposition of Au-Pt bimetallic nanoparticles on $\mathrm{MoS}_{2}$ nanoflowers for hydrogen peroxide enzyme-free electrochemical sensor. Electrochim. Acta 2017, 250, 152-158. [CrossRef]

88. Yang, Y.; Gao, P.; Ren, X.; Sha, L.; Yang, P.; Zhang, J.; Chen, Y.; Yang, L. Massive Ti ${ }^{3+}$ self-doped by the injected electrons from external $\mathrm{Pt}$ and the efficient photocatalytic hydrogen production under visible-Light. Appl. Catal. B Environ. 2017, 218, 751-757. [CrossRef]

89. Fang, J.; Gu, J.; Liu, Q.; Zhang, W.; Su, H.; Zhang, D. Three-Dimensional CdS/Au Butterfly Wing Scales with Hierarchical Rib Structures for Plasmon-Enhanced Photocatalytic Hydrogen Production. ACS Appl. Mater. Interfaces 2018, 10, 19649-19655. [CrossRef] [PubMed]

90. Chang, Y.; Yu, K.; Zhang, C.; Yang, Z.; Feng, Y.; Hao, H.; Jiang, Y.; Lou, L.-L.; Zhou, W.; Liu, S. Ternary CdS/ $\mathrm{Au} / 3 \mathrm{DOM}-\mathrm{SrTiO}_{3}$ composites with synergistic enhancement for hydrogen production from visible-light photocatalytic water splitting. Appl. Catal. B Environ. 2017, 215, 74-84. [CrossRef]

91. Masudy-Panah, S.; Siavash Moakhar, R.; Chua, C.S.; Kushwaha, A.; Dalapati, G.K. Stable and Efficient $\mathrm{CuO}$ Based Photocathode through Oxygen-Rich Composition and Au-Pd Nanostructure Incorporation for Solar-Hydrogen Production. ACS Appl. Mater. Interfaces 2017, 9, 27596-27606. [CrossRef] [PubMed]

92. Ortiz, N.; Zoellner, B.; Hong, S.J.; Ji, Y.; Wang, T.; Liu, Y.; Maggard, P.A.; Wang, G. Harnessing Hot Electrons from Near IR Light for Hydrogen Production Using Pt-End-Capped-AuNRs. ACS Appl. Mater. Interfaces 2017, 9, 25962-25969. [CrossRef]

93. Wang, Y.; Zhao, J.; Li, Y.; Wang, C. Selective photocatalytic $\mathrm{CO}_{2}$ reduction to $\mathrm{CH}_{4}$ over $\mathrm{Pt} / \mathrm{In}_{2} \mathrm{O}_{3}$ : Significant role of hydrogen adatom. Appl. Catal. B Environ. 2018, 226, 544-553. [CrossRef]

94. Jiang, J.-Z.; Ren, L.-Q.; Huang, Y.-P.; Li, X.-D.; Wu, S.-H.; Sun, J.-J. 3D Nanoporous Gold-Supported Pt Nanoparticles as Highly Accelerating Catalytic Au-Pt Micromotors. Adv. Mater. Interfaces 2018, 5, 1701689. [CrossRef]

95. Lang, Q.; Chen, Y.H.; Huang, T.L.; Yang, L.N.; Zhong, S.X.; Wu, L.J.; Chen, J.R.; Bai, S. Graphene 'bridge' in transferring hot electrons from plasmonic Ag nanocubes to $\mathrm{TiO}_{2}$ nanosheets for enhanced visible light photocatalytic hydrogen evolution. Appl. Catal. B Environ. 2018, 220, 182-190. [CrossRef]

96. Zhang, Y.; Park, S.-J. Facile construction of $\mathrm{MoO}_{3} @ Z$ ZIF-8 core-shell nanorods for efficient photoreduction of aqueous Cr (VI). Appl. Catal. B Environ. 2019, 240, 92-101. [CrossRef]

97. Kamijyo, K.; Takashima, T.; Yoda, M.; Osaki, J.; Irie, H. Facile synthesis of a red light-inducible overall water-splitting photocatalyst using gold as a solid-state electron mediator. Chem. Commun. 2018, 54, 7999-8002. [CrossRef] [PubMed]

98. Maeda, K.; Domen, K. Photocatalytic Water Splitting: Recent Progress and Future Challenges. J. Phys. Chem. Lett. 2010, 1, 2655-2661. [CrossRef]

99. Iwase, A.; Ng, Y.H.; Ishiguro, Y.; Kudo, A.; Amal, R. Reduced graphene oxide as a solid-state electron mediator in Z-scheme photocatalytic water splitting under visible light. J. Am. Chem. Soc. 2011, 133, 11054-11057. [CrossRef] [PubMed]

100. Zhang, Y.; Park, S.-J. Formation of hollow $\mathrm{MoO}_{3} / \mathrm{SnS}_{2}$ heterostructured nanotubes for efficient light-driven hydrogen peroxide production. J. Mater. Chem. A 2018, 6, 20304-20312. [CrossRef]

101. Xu, C.; Qiu, P.; Li, L.; Chen, H.; Jiang, F.; Wang, X. Bismuth Subcarbonate with Designer Defects for Broad-Spectrum Photocatalytic Nitrogen Fixation. ACS Appl. Mater. Interfaces 2018, 10, 25321-25328. [CrossRef] [PubMed] 
102. Kobayashi, R.; Takashima, T.; Tanigawa, S.; Takeuchi, S.; Ohtani, B.; Irie, H. A heterojunction photocatalyst composed of zinc rhodium oxide, single crystal-derived bismuth vanadium oxide, and silver for overall pure-water splitting under visible light up to $740 \mathrm{~nm}$. Phys. Chem. Chem. Phys. PCCP 2016, 18, 27754-27760. [CrossRef] [PubMed]

103. Iwashina, K.; Iwase, A.; $\mathrm{Ng}$, Y.H.; Amal, R.; Kudo, A. Z-schematic water splitting into $\mathrm{H}_{2}$ and $\mathrm{O}_{2}$ using metal sulfide as a hydrogen-evolving photocatalyst and reduced graphene oxide as a solid-state electron mediator. J. Am. Chem. Soc. 2015, 137, 604-607. [CrossRef] [PubMed]

104. Yu, X.; Liu, G.; Li, W.; An, L.; Li, Z.; Liu, J.; Hu, P. Mesocrystalline $\mathrm{Ta}_{2} \mathrm{O}_{5}$ nanosheets supported Pd Pt nanoparticles for efficient photocatalytic hydrogen production. Int. J. Hydrogen Energy 2018, 43, 8232-8242. [CrossRef]

105. Low, J.; Yu, J.; Jaroniec, M.; Wageh, S.; Al-Ghamdi, A.A. Heterojunction Photocatalysts. Adv. Mater. 2017, 29, 1601694. [CrossRef] [PubMed]

106. Zhu, M.; Zhai, C.; Fujitsuka, M.; Majima, T. Noble metal-free near-infrared-driven photocatalyst for hydrogen production based on 2D hybrid of black Phosphorus/WS 2 . Appl. Catal. B Environ. 2018, 221, 645-651. [CrossRef]

107. Do, J.Y.; Lee, J.H.; Park, N.-K.; Lee, T.J.; Lee, S.T.; Kang, M. Synthesis and characterization of $\mathrm{Ni}_{2}-\mathrm{xPd}_{\mathrm{x}} \mathrm{MnO}_{4} / \gamma-\mathrm{Al}_{2} \mathrm{O}_{3}$ catalysts for hydrogen production via propane steam reforming. Chem. Eng. J. 2018, 334, 1668-1678. [CrossRef]

108. Qin, Z.; Xue, F.; Chen, Y.; Shen, S.; Guo, L. Spatial charge separation of one-dimensional $\mathrm{Ni}_{2} \mathrm{P}-\mathrm{Cd}_{0.9} \mathrm{Zn}_{0.1} \mathrm{~S} / \mathrm{g}-\mathrm{C}_{3} \mathrm{~N}_{4}$ heterostructure for high-quantum-yield photocatalytic hydrogen production. Appl. Catal. B Environ. 2017, 217, 551-559. [CrossRef]

109. Hu, Z.; Wang, X.; Dong, H.; Li, S.; Li, X.; Li, L. Efficient photocatalytic degradation of tetrabromodiphenyl ethers and simultaneous hydrogen production by $\mathrm{TiO}_{2}-\mathrm{Cu}_{2} \mathrm{O}$ composite films in $\mathrm{N}_{2}$ atmosphere: Influencing factors, kinetics and mechanism. J. Hazard. Mater. 2017, 340, 1-15. [CrossRef]

110. Iervolino, G.; Vaiano, V.; Sannino, D.; Rizzo, L.; Galluzzi, A.; Polichetti, M.; Pepe, G.; Campiglia, P. Hydrogen production from glucose degradation in water and wastewater treated by $\mathrm{Ru}-\mathrm{LaFeO} \mathrm{O}_{3} / \mathrm{Fe}_{2} \mathrm{O}_{3}$ magnetic particles photocatalysis and heterogeneous photo-Fenton. Int. J. Hydrogen Energy 2018, 43, 2184-2196. [CrossRef]

111. Imran, M.; Yousaf, A.B.; Kasak, P.; Zeb, A.; Zaidi, S.J. Highly efficient sustainable photocatalytic Z-scheme hydrogen production from an $\alpha-\mathrm{Fe}_{2} \mathrm{O}_{3}$ engineered $\mathrm{ZnCdS}$ heterostructure. J. Catal. 2017, 353, 81-88. [CrossRef]

112. Subha, N.; Mahalakshmi, M.; Myilsamy, M.; Neppolian, B.; Murugesan, V. Direct Z-scheme heterojunction nanocomposite for the enhanced solar $\mathrm{H}_{2}$ production. Appl. Catal. A Gen. 2018, 553, 43-51. [CrossRef]

113. Zhang, J.; Yan, W.; An, Z.; Song, H.; He, J. Interface-Promoted Dehydrogenation and Water-Gas Shift toward High-Efficient $\mathrm{H}_{2}$ Production from Aqueous Phase Reforming of Cellulose. ACS Sustain. Chem. Eng. 2018, 6, 7313-7324. [CrossRef]

114. Vinodgopal, K.; Kamat, P.V. Enhanced rates of photocatalytic degradation of an azo dye using $\mathrm{SnO}_{2} / \mathrm{TiO}_{2}$ coupled semiconductor thin films. Environ. Sci. Technol. 1995, 29, 841-845. [CrossRef] [PubMed]

115. Ranjit, K.; Viswanathan, B. Synthesis, characterization and photocatalytic properties of iron-doped $\mathrm{TiO}_{2}$ catalysts. J. Photochem. Photobiol. A 1997, 108, 79-84. [CrossRef]

116. Monai, M.; Montini, T.; Fonda, E.; Crosera, M.; Delgado, J.J.; Adami, G.; Fornasiero, P. Nanostructured Pd Pt nanoparticles: Evidences of structure/performance relations in catalytic $\mathrm{H}_{2}$ production reactions. Appl. Catal. B Environ. 2018, 236, 88-98. [CrossRef]

117. Wang, Q.; He, J.; Shi, Y.; Zhang, S.; Niu, T.; She, H.; Bi, Y.; Lei, Z. Synthesis of $\mathrm{MFe}_{2} \mathrm{O}_{4}(\mathrm{M}=\mathrm{Ni}, \mathrm{Co}) / \mathrm{BiVO}_{4}$ film for photolectrochemical hydrogen production activity. Appl. Catal. B Environ. 2017, 214, 158-167. [CrossRef]

118. Xu, J.; Gao, J.; Qi, Y.; Wang, C.; Wang, L. Anchoring $\mathrm{Ni}_{2} \mathrm{P}$ on the UiO-66- $\mathrm{NH}_{2} / \mathrm{g}-\mathrm{C}_{3} \mathrm{~N}_{4}$-derived C-doped $\mathrm{ZrO}_{2} / \mathrm{g}-\mathrm{C}_{3} \mathrm{~N}_{4}$ Heterostructure: Highly Efficient Photocatalysts for $\mathrm{H}_{2}$ Production from Water Splitting. ChemCatChem 2018, 10, 3327-3335. [CrossRef]

119. Wang, Z.; Jin, Z.; Wang, G.; Ma, B. Efficient hydrogen production over MOFs (ZIF-67) and g- $\mathrm{C}_{3} \mathrm{~N}_{4}$ boosted with $\mathrm{MoS}_{2}$ nanoparticles. Int. J. Hydrogen Energy 2018, 43, 13039-13050. [CrossRef]

120. Fu, J.; Zhu, B.; You, W.; Jaroniec, M.; Yu, J. A flexible bio-inspired $\mathrm{H}_{2}$ - production photocatalyst. Appl. Catal. B Environ. 2018, 220, 148-160. [CrossRef] 
121. Zhang, S.; Liu, X.; Liu, C.; Luo, S.; Wang, L.; Cai, T.; Zeng, Y.; Yuan, J.; Dong, W.; Pei, Y.; et al. MoS M $_{2}$ Quantum Dot Growth Induced by $S$ Vacancies in a $\mathrm{ZnIn}_{2} \mathrm{~S}_{4}$ Monolayer: Atomic-Level Heterostructure for Photocatalytic Hydrogen Production. ACS Nano 2018, 12, 751-758. [CrossRef] [PubMed]

122. Li, K.; Gao, S.; Wang, Q.; Xu, H.; Wang, Z.; Huang, B.; Dai, Y.; Lu, J. In-Situ-Reduced Synthesis of Ti(3)(+) Self-Doped $\left.\left.\mathrm{TiO}_{2}\right) / \mathrm{g}-\mathrm{C}\left({ }_{3}\right) \mathrm{N}_{4}\right)$ Heterojunctions with High Photocatalytic Performance under LED Light Irradiation. ACS Appl. Mater. Interfaces 2015, 7, 9023-9030. [CrossRef] [PubMed]

123. Hong, S.J.; Lee, S.; Jang, J.S.; Lee, J.S. Heterojunction $\mathrm{BiVO}_{4} / \mathrm{WO}_{3}$ electrodes for enhanced photoactivity of water oxidation. Energy Environ. Sci. 2011, 4, 1781-1787. [CrossRef]

124. Huang, L.; Xu, H.; Li, Y.; Li, H.; Cheng, X.; Xia, J.; Xu, Y.; Cai, G. Visible-light-induced $\mathrm{WO}_{3} / g-\mathrm{C}_{3} \mathrm{~N}_{4}$ composites with enhanced photocatalytic activity. Dalton Trans. 2013, 42, 8606-8616. [CrossRef] [PubMed]

125. Pan, C.; Xu, J.; Wang, Y.; Li, D.; Zhu, Y. Dramatic Activity of $\mathrm{C}_{3} \mathrm{~N}_{4} / \mathrm{BiPO}_{4}$ Photocatalyst with Core/Shell Structure Formed by Self-Assembly. Adv. Funct. Mater. 2012, 22, 1518-1524. [CrossRef]

126. Zhang, J.; Qiao, S.Z.; Qi, L.; Yu, J. Fabrication of NiS modified CdS nanorod p-n junction photocatalysts with enhanced visible-light photocatalytic $\mathrm{H}_{2}$-production activity. Phys. Chem. Chem. Phys. PCCP 2013, 15, 12088-12094. [CrossRef]

127. Heo, Y.-J.; Zhang, Y.; Rhee, K.Y.; Park, S.-J. Synthesis of PAN/PVDF nanofiber composites-based carbon adsorbents for $\mathrm{CO}_{2}$ capture. Compos. Part B Eng. 2019, 156, 95-99. [CrossRef]

128. Zhang, Y.; Park, M.; Kim, H.Y.; Park, S.J. Moderated surface defects of Ni particles encapsulated with NiO nanofibers as supercapacitor with high capacitance and energy density. J. Colloid Interface Sci. 2017, 500, 155-163. [CrossRef]

(C) 2018 by the authors. Licensee MDPI, Basel, Switzerland. This article is an open access article distributed under the terms and conditions of the Creative Commons Attribution (CC BY) license (http:/ / creativecommons.org/licenses/by/4.0/). 